\title{
Primary open angle glaucoma due to T377M MYOC: Population mapping of a Greek founder mutation in Northwestern Greece
}

This article was published in the following Dove Press journal:

Clinical Ophthalmology

16 March 2010

Number of times this article has been viewed

\section{George Kitsos' \\ Zacharias Petrou ${ }^{2}$ \\ Maria Grigoriadou ${ }^{3}$ \\ John R Samples ${ }^{4}$ \\ Alex W Hewitt ${ }^{5}$ \\ Haris Kokotas ${ }^{3}$ \\ Aglaia Giannoulia-Karantana ${ }^{3}$ \\ David A Mackey ${ }^{6}$ \\ Mary K Wirtz \\ Marilita Moschou \\ John PA loannidis ${ }^{8}$ \\ Michael B Petersen ${ }^{3}$ \\ 'Department of Ophthalmology, University of loannina, School \\ of Medicine, loannina, Greece; \\ 2Department of Ophthalmology, \\ General Hospital of loannina \\ "G Chatzikosta", loannina, Greece; \\ ${ }^{3}$ Department of Genetics, Institute \\ of Child Health, Athens, Greece; \\ ${ }^{4}$ Department of Ophthalmology, \\ Casey Eye Institute-OHSU, Portland, \\ OR; ${ }^{5}$ Department of Ophthalmology, \\ Flinders University, Adelaide, Australia; \\ ${ }^{6}$ Center for Eye Research Australia, \\ University of Melbourne, Royal \\ Victorian Eye and Ear Hospital, \\ Melbourne, Australia; ${ }^{7}$ Department \\ of Ophthalmology, University of \\ Athens, School of Medicine, Athens, \\ Greece; ${ }^{8}$ Department Hygiene and \\ Epidemiology, University of loannina, \\ School of Medicine, loannina, Greece}

Correspondence: George Kitsos Associate Professor of Ophthalmology,

Department of Ophthalmology,

University of loannina, School of

Medicine, 45I I0, loannina, Greece

Tel +302651042504

$\mathrm{Fax}+302651049709$

Email gkitsos@cc.uoi.gr
Background: Mutations in the $M Y O C$ gene have been shown to explain 5\% of unrelated primary open angle glaucoma (POAG) in different populations. In particular, the T377M MYOC mutation has arisen at least three separate times in history, in Great Britain, India, and Greece. The purpose of this study is to investigate the distribution of the mutation among different population groups in the northwestern region of Greece.

Materials and methods: We explored the distribution of the "Greek" T377M founder mutation in the Epirus region in Northwestern Greece, which could be its origin. Genotyping was performed in POAG cases and controls by PCR amplification of the MYOC gene, followed by digestion with restriction enzyme. Statistical analyses were performed by an exact test, the Kaplan-Meier method and the t-test.

Results: In the isolated Chrysovitsa village in the Pindus Mountains, a large POAG family demonstrated the T377M mutation in 20 of 66 family members while no controls from the Epirus region $(\mathrm{n}=124)$ carried this mutation $(P<0.001)$. Among other POAG cases from Epirus, 2 out of 14 familial cases and 1 out of 80 sporadic cases showed the mutation $(P=0.057)$. The probability of POAG diagnosis with advancing age among mutation carriers was $23 \%$ at age 40 , and reached $100 \%$ at age 75 . POAG patients with the T377M mutation were diagnosed at a mean age of 51 years $(\mathrm{SD} \pm 13.9)$, which is younger than the sporadic or familial POAG cases: $63.1(\mathrm{SD} \pm 11)$ and $66.8(\mathrm{SD} \pm 9.8)$ years, respectively.

Conclusions: The T377M mutation was found in high proportion in members of the Chrysovitsa family (30.3\%), in lower proportion in familial POAG cases $(14.2 \%)$ and seems rare in sporadic POAG cases $(1.2 \%)$, while no controls $(0 \%)$ from the Epirus region carried the mutation. Historical and geographical data may explain the distribution of this mutation within Greece and worldwide.

Keywords: primary open angle glaucoma, $G L C 1 C$, myocilin, $M Y O C$, founder mutation

\section{Introduction}

Glaucoma is a heterogeneous group of disorders resulting from optic nerve damage and is the second leading cause of irreversible blindness worldwide. Primary open angle glaucoma (POAG) is the most common form, with reported prevalence rates ranging from $1.1 \%{ }^{1}$ to $3.8 \% .^{2}$ The definition of glaucoma has changed many times as the etiology and pathogenetic pathways are still largely unknown. A high intraocular pressure (IOP) is no longer considered part of the definition of POAG, but represents a risk factor for the development of $\mathrm{POAG}{ }^{3}$ Other risk factors are old age, race, and positive family history. ${ }^{4}$ At the genetic level, a distinction between juvenile onset (age at diagnosis 10-35 years) and adult onset (age at diagnosis above 35 years) has been made. 
Many juvenile onset cases have autosomal dominant inheritance whilst adult onset cases are typically multifactorial.

The first locus related to juvenile onset glaucoma was mapped to chromosome 1q21-q31 (GLC1A). ${ }^{5}$ A common POAG locus for both juvenile and adult onset POAG was suggested from the study of a large Canadian family with linkage to the $G L C 1 A$ locus and different ages of onset. ${ }^{6}$ Other pedigrees with adult onset POAG excluded linkage to the $G L C 1 A$ locus. ${ }^{7,8}$ The gene encoding myocilin (MYOC), located in 1q23-q24, consists of 3 exons, and shows high expression in the trabecular meshwork and ciliary body. ${ }^{9}$ Mutations in the $M Y O C$ gene were finally identified as responsible for glaucoma at the GLC1A locus. ${ }^{9}$ Large studies have demonstrated that point mutations in $M Y O C$ account for $4.6 \%$ of unrelated POAG patients. ${ }^{10}$ Patients with POAG due to $M Y O C$ mutations show marked phenotypic variation with age at diagnosis ranging from 8 to 77 years and highest recorded IOP ranging from 12 to $77 \mathrm{~mm} \mathrm{Hg} .{ }^{10}$ To date approximately 60 disease-causing $M Y O C$ mutations have been reported, and a genotype-phenotype correlation exists. ${ }^{11}$

Evidence for founder effects of several MYOC mutations has been reported in different populations. ${ }^{12-16}$ The T377M mutation was first described in 1998 and has since been identified in populations from five different continents. ${ }^{17-25}$ An investigation of founder effects for this mutation has demonstrated that it has arisen at least three separate times, namely in Great Britain, India, and Greece. ${ }^{16}$ The purpose of the present study is to determine the prevalence of the Greek T377M founder mutation in familial and sporadic cases of POAG and unaffected controls in Epirus, the Northwestern region of Greece, and to discuss geographical and historical data to assist explaining the propagation of this mutation in Greece and worldwide. We also describe the clinical characteristics of the T377M mutation carriers in our material.

\section{Materials and methods}

Sporadic and familial POAG patients from Epirus, Northwest Greece, as well as unaffected controls from the same region were recruited. POAG patients were recruited from the Glaucoma Unit of the Department of Ophthalmology, University of Ioannina School of Medicine, or from the Department of Ophthalmology, General Hospital of Ioannina "G. Chatzikosta". All 200 POAG patients seen in follow-up between April 2005 and January 2006 at the two hospitals were asked to participate in the study and 94 of them gave their consent and had blood drawn for genetic testing. The 106 non responders for blood testing, had POAG of the same severity (max IOP, c/d ratio, visual fields) and their ethnicity, their age at diagnosis, age at examination and sex matched the group that gave their consent. These two hospitals cover the entire Epirus region. Of the 94 cases, 80 were sporadic and 14 had a positive family history of POAG, which was confirmed by clinical examination of family members.

Members of a large family with POAG segregating as a monogenic trait $(G L C 1 C)$ were recruited from a previous study. ${ }^{26}$ The T377M MYOC mutation was found to segregate in a large proportion of the members of this family. ${ }^{24}$ The family originated from the Chrysovitsa village of the Pindus Mountains, Epirus. A total of 66 out of 73 family members were available for the present study. Furthermore, we included 4 sporadic POAG cases and 4 individuals without POAG (controls) from the Chrysovitsa village, who were not related to the pedigree described above, and which are included in the sporadic POAG and control groups, respectively.

Unaffected Epirus residents were selected as controls from patients admitted to cataract surgery in the Department of Ophthalmology, General Hospital of Ioannina "G Chatzikosta", between April 2005 and January 2006. A total number of 124 controls were recruited, of which 24 individuals had pseudoexfoliative material in the anterior chamber of one or both eyes (without glaucoma).

The protocol was approved by the Ethics Committees of the University of Ioannina School of Medicine, the General Hospital of Ioannina "G Chatzikosta", and the Institute of Child Health, Athens. The clinical examination protocol included an interview to determine the presence of family history of POAG, full medical history, and history of ophthalmologic disorders. Applanation tonometry was performed with a recently calibrated Goldmann applanation tonometer (Haag Streit AG, Bern, Switzerland). The anterior segment was examined by slit lamp biomicroscopy including gonioscopy. Optic disc appearance was evaluated and the cup/disc ratio was measured. Qualitative signs of POAG, such as bared circumpapillary vessels, disc hemorrhages, focal neuroretinal rim thinning or a notch extending to the margin, as well as retinal fiber layer defects, were assessed with a stereoscopic fundus lens (Volk Optical Inc., Mentor, Ohio). Automated perimetry by Humphrey 24-2 (Humphrey Inc., San Leandro, CA, USA) was performed to determine visual field defects in the POAG patients. Staging of the perimetry results (Early Glaucomatous Loss, Moderate Glaucomatous Loss and Advanced Glaucomatous Loss) was done according to Hodapp classification, as suggested by the European Glaucoma Society. ${ }^{27,28}$ Ocular hypertension (OHT) was defined as IOP $\geq 21 \mathrm{~mm} \mathrm{Hg}$, with all other ocular findings within normal limits. The criteria for the diagnosis of POAG were according to the guidelines of the European 
Glaucoma Society. ${ }^{27}$ Patients with pseudoexfoliation glaucoma were excluded from the study. The clinical examination protocol, except for the automated perimetry, was also performed in the controls.

Venous blood was drawn from patients and controls following informed consent, and DNA was obtained by a salt extraction method..$^{29}$ Genotyping of the T377M MYOC mutation was performed by PCR amplification of genomic DNA using a modified protocol of Melki et al. ${ }^{22}$ The primers used were MYOC-F (5'-GATTATGGATTAAGTGGTGCTTCG-3') and MYOC-R (5' - TGAGCATCTCCTTCTGCCATTGCC - 3'). A fragment of $874 \mathrm{bp}$ was amplified according to the following protocol: $94^{\circ} \mathrm{C}$ for 5 minutes, followed by 35 cycles of $94^{\circ} \mathrm{C}$ for 30 seconds, $58^{\circ} \mathrm{C}$ for 30 seconds, $72^{\circ} \mathrm{C}$ for 1 minute, and final extension of $72^{\circ} \mathrm{C}$ for 7 minutes. The unpurified PCR product was subsequently digested with Hsp92 II enzyme (Promega Corporation, Madison, Wisconsin) at $37^{\circ} \mathrm{C}$ for 24 hours and digests were run on a $9 \%$ polyacrylamide gel in TBE buffer at $90 \mathrm{~V}$ for 3 hours. HSP92II recognizes a CATG restriction site, and therefore, the wild-type DNA yielded 3 fragments of 740, 80, and $54 \mathrm{bp}$, while the T377M mutation creates a restriction site with fragments of 443, 297, 80, and 54 bp (Figure 1).

Mutation carrier rates between groups were compared with an exact test. Time-to-POAG diagnosis analysis used the Kaplan-Meier method. Comparison of continuous measures used the t-test. $P$ values were two-tailed.

\section{Results}

\section{Prevalence of T377M in various groups}

The results of T377M MYOC genotyping in POAG patients and unaffected controls are summarized in Table 1. In the Chrysovitsa family segregating POAG as an autosomal dominant trait, 20 out of 66 family members $(30.3 \%)$ carried the T377M mutation. Two out of 14 Epirus POAG cases $(14.2 \%)$ with positive family history had the T377M

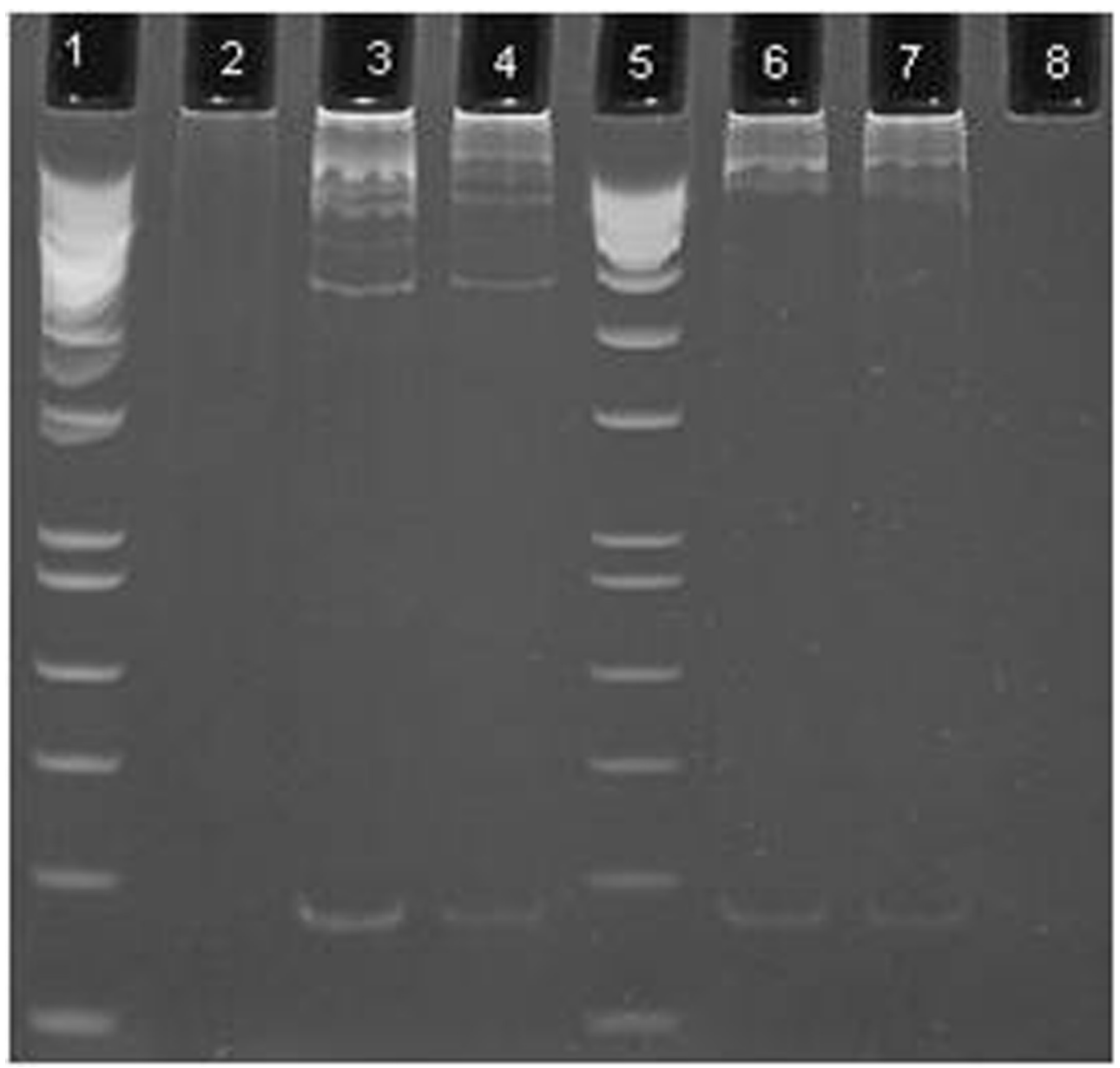

Figure I Examples of the results obtained from the molecular analysis. Lanes I and 5: PhiXI74 DNA/Hinfl marker; Lanes 2 and 8: blank; Lanes 3 and 4: heterozygotes for the T377M mutation (740 bp, 443 bp, 297 bp, and 80 bp bands are visible); Lanes 6 and 7: normal DNA samples not harboring the T377M mutation (740 bp, and 80 bp bands are visible). The 54 bp band was not visible in the gel. 
Table I Frequency of the T377M MYOC mutation in different categories of examined individuals from Epirus, Greece

\begin{tabular}{llll}
\hline Groups & Number of individuals & Number of T377M carriers & Proportion $(95 \%$ Cl) \\
\hline Sporadic POAG (Epirus) & $80^{\mathrm{a}}$ & $\mathrm{I}$ & $1.2(0.0-6.8)$ \\
Familial POAG (Epirus) & $14^{\mathrm{b}}$ & 2 & $14.2(1.8-42.8)$ \\
Chrysovitsa family & $66^{\mathrm{c}}$ & $20^{\mathrm{d}}$ & $30.3(19.6-42.9)$ \\
Epirus controls & $124^{\mathrm{e}}$ & 0 & $0.0(0.0-2.9)$ \\
Sporadic POAG (Chrysovitsa) & 4 & 0 & $0.0(0.0-60.2)$ \\
Chrysovitsa controls & 4 & 0 & $0.0(0.0-60.2)$ \\
\hline
\end{tabular}

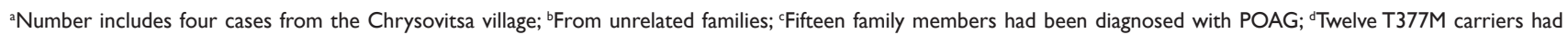
POAG; ${ }^{N}$ Number includes 4 individuals from the Chrysovitsa village.

Abbreviation: POAG, primary open-angle glaucoma.

mutation, whereas only one out of 80 sporadic Epirus POAG cases $(1.2 \%)$ carried this mutation (exact $P=0.057$ for the comparison of familial versus sporadic POAG cases). Furthermore, the T377M mutation was not detected among 124 Epirus inhabitants without POAG (controls) (exact $P<0.001$ for the comparison against POAG cases). Moreover, none of the four sporadic POAG cases from the Chrysovitsa village (not belonging to the large family described above) had the T377M mutation.

\section{Clinical features for T377M carriers with POAG}

The clinical findings in carriers of the T377M mutation from Epirus are presented in Table 2. Of these, 15 had a diagnosis of POAG (12 from the Chrysovitsa family, 2 other familial cases, 1 sporadic case). Eight cases of POAG had severe visual defects and 7 had modest visual defects. In Kaplan-Meier analysis, the probability of POAG diagnosis with advancing age among mutation carriers was $23 \%$ at age 40 , and reached $100 \%$ at age 75 . Three individuals had undergone surgery in both eyes (trabeculectomy) and one (F3-38) definitely needed surgical therapy but was unwilling to comply. Also, in T377M mutation carriers, the probability of developing glaucoma with advancing age in $G L C 1 C$ and non-GLC1C individuals is shown in a Kaplan-Meier plot in Figure 2.

\section{Clinical features in POAG: T377M carriers versus non-carriers}

The mean age at diagnosis $\pm \mathrm{SD}$, mean age at examination \pm $\mathrm{SD}$, mean maximum IOP $\pm \mathrm{SD}$, and mean maximum cup/ disc ratio $\pm \mathrm{SD}$ in the various groups of Epirus individuals are presented in Table 3. POAG patients with the T377M mutation were diagnosed at $51 \pm 13.9$ years of age, which is younger than the sporadic or familial POAG cases without T377M: $63.1 \pm 11$ and $66.8 \pm 9.8$ years of age, respectively $(P<0.001$ for POAG cases with versus without T377M).
The mean maximum IOP $(31.9 \pm 8.5 \mathrm{~mm} \mathrm{Hg})$ was not much higher in the T377M POAG group than in the sporadic or familial POAG groups without T377M $(28.1 \pm 7.1 \mathrm{~mm} \mathrm{Hg}$ and $29.1 \pm 6.3 \mathrm{~mm} \mathrm{Hg}$, respectively). Finally, there were no significant differences in the cup/disc ratio for T377M carriers versus non-carriers with POAG (Table 3).

\section{Discussion}

We have examined the prevalence of the T377M MYOC mutation in diverse groups of patients with POAG and unaffected controls in the region of Epirus in Northwestern Greece. Our findings suggest that T377M is largely concentrated in the originally described family from Chrysovitsa, where almost one in four members $(15 / 66)$ are affected by POAG. ${ }^{26}$ However, some other familial glaucoma cases from the region also carry this mutation, while the mutation is very rare in sporadic POAG cases and virtually absent in unaffected controls from the general Epirus population. POAG associated with T377M in this region is associated with early onset in a substantial proportion of cases and practically complete penetrance of the disease by age 75 , but otherwise the severity of the illness is not much worse compared with cases without T377M from the same region.

Hereditary diseases are occasionally frequent in small populations that have been living in relative isolation for a long time. When a mutation was introduced by a founder in an isolated population, it could have a chance to become frequent even in spite of selection against it. One such example of an isolated population is the Northwest region of Greece, Epirus. The Chrysovitsa village in the Pindus Mountains of the Epirus region of Greece has been isolated for centuries. Eleven pedigrees from Epirus segregating adult onset POAG in an autosomal dominant mode were described by Kitsos et al. ${ }^{30}$ Linkage analysis in the largest of these pedigrees, habitating the small village of Chrysovitsa (population of 993 in 2001) on Mount Pindus, showed linkage to the GLC1C locus 
Table 2 Clinical findings in carriers of the T377M MYOC mutation from Epirus, Greece

\begin{tabular}{|c|c|c|c|c|c|c|c|c|c|}
\hline ID $^{\mathbf{a}}$ & $\begin{array}{l}\text { Year of } \\
\text { birth }\end{array}$ & POAG & GLCIC & $\begin{array}{l}\text { Age at } \\
\text { examination }\end{array}$ & $\begin{array}{l}\text { Age at } \\
\text { diagnosis }\end{array}$ & $\begin{array}{l}\text { Max } \\
\text { intraocular } \\
\text { pressure }\end{array}$ & $\begin{array}{l}\text { Max cup/ } \\
\text { disc ratio }\end{array}$ & $\begin{array}{l}\text { Visual } \\
\text { fields }\end{array}$ & $\begin{array}{l}\text { Surgery } \\
\text { (trabeculectomy) }\end{array}$ \\
\hline F2-3 & 1909 & Yes & Yes & 85 & 75 & 28 & 0.9 & SD & No \\
\hline$F 2-5$ & 1917 & Yes & Yes & 84 & 67 & 56 & 0.95 & SD & No \\
\hline$F 2-6$ & 1924 & Yes & Yes & 77 & 60 & 23 & 0.8 & SD & No \\
\hline F2-7 & 1927 & Yes & Yes & 74 & 57 & 26 & 0.4 & MD & No \\
\hline F2-8 & 1930 & Yes & Yes & 71 & 54 & 43 & 0.9 & SD & No \\
\hline F3-6 & 1949 & Yes & & 55 & 36 & 30 & 0.6 & MD & No \\
\hline F3-II & 1940 & No & & 69 & & 18 & 0.3 & & No \\
\hline F3-14 & 1949 & No & & 60 & & 19 & 0.2 & & No \\
\hline F3-19 & $195 \mid$ & No & & 58 & & 20 & 0.2 & & No \\
\hline F3-22 & 1948 & No & Yes & 61 & & 19 & 0.3 & & No \\
\hline F3-25 & 1957 & Yes & & 44 & 34 & 36 & 0.5 & MD & Yes OD/OS \\
\hline F3-38 & 1960 & Yes & Yes & $4 I$ & 36 & 30 & 0.7 & SD & No \\
\hline F3-27 & 1947 & No & & 62 & & 14 & 0.3 & & No \\
\hline F3-29 & 1955 & Yes & Yes & 54 & 39 & 27 & 0.5 & MD & No \\
\hline F3-37 & 1958 & Yes & & 51 & 46 & 32 & 0.6 & MD & No \\
\hline F3-3I & 1958 & Yes & & 43 & 43 & 26 & 0.5 & MD & No \\
\hline F3-32 & 1959 & $\mathrm{OHT}$ & & 50 & & 22 & 0.2 & & No \\
\hline F3-34 & 1964 & No & Yes & 45 & & 20 & 0.4 & & No \\
\hline F3-35 & 1970 & Yes & Yes & 35 & 32 & 36 & 0.9 & SD & No \\
\hline F4-27 & 1980 & No & & 29 & & 16 & 0.4 & & No \\
\hline 20DC & 1928 & Yes & & 80 & 70 & 27 & 0.8 & SD & Yes OD/OS \\
\hline KI5I & 1946 & Yes & & 59 & 58 & 24 & 0.7 & MD & No \\
\hline KI53 & 1925 & Yes & & 80 & 67 & 35 & 0.9 & SD & Yes OD/OS \\
\hline
\end{tabular}

${ }^{2}$ The $\mathrm{F}$ individuals indicate members of the Chrysovitsa family, the 20DC individual is a sporadic POAG case, whereas the $\mathrm{K}$ individuals are familial POAG cases. Abbreviations: SD, severe defect - advanced glaucomatous loss; MD, moderate defect - moderate glaucomatous loss; OHT, ocular hypertension; POAG, primary open-angle glaucoma; OD, right eye; OS, left eye.

at 3q21-q24, ${ }^{26}$ which had originally been described in a large family from Oregon, USA. ${ }^{31}$ Due to the usually multifactorial mode of inheritance of adult onset POAG, both GLC1C families were screened for mutations in the $M Y O C$ gene. ${ }^{24}$ Interestingly, the T377M mutation was found in $67 \%(10 / 15)$ of the POAG patients of the Chrysovitsa family in an earlier evaluation of the same family. ${ }^{24}$ Taxiarchis, another small Greek village ( 1100 inhabitants) on Mount Holomondas in the Chalkidiki region, known to be enriched for familial glaucoma, ${ }^{32}$ was recently studied by Wirtz et al..$^{33}$ The incidence of glaucoma was $17 \%(22 / 126)$ and the T377M MYOC mutation was detected in 59\% (13/22) of the POAG patients. The haplotype of the T377M mutation in Taxiarchis villagers was the same as in the Chrysovitsa villagers. ${ }^{33}$

As evident from Table 1, acknowledging that some of the data are sparse, the mutation seems to occur in a considerable proportion of familial POAG cases from Epirus, as compared to the low proportion found in the sporadic POAG cases from the same region. One of the T377M mutation carriers (K151 - Table 2), a 63-year-old lady of Vlach ancestry (both parents) with familial glaucoma, was born in Kefalovryso (father and her 2 sisters: POAG patients). The other familial case (K153 - Table 2), an 84-year-old man, was born in Perdika ( $4 / 5$ brothers and his son: POAG patients). The T377M sporadic case (20DC - Table 2) originates from Kastritsa (both parents and all 5 brothers/sisters: healthy - no POAG). The above 3 small villages are located at a $60-70 \mathrm{~km}$ distance from Chrysovitsa (Figure 3). None of these individuals has any known relation to Chrysovitsa going back 2 generations (origin of grandparents). The Taxiarchis village is located about $300 \mathrm{~km}$ from Chrysovitsa and there is oral information from Taxiarchis villagers that a route existed between the two villages, which was traveled frequently, at times to bring young women from Chrysovitsa to Taxiarchis for marriage 


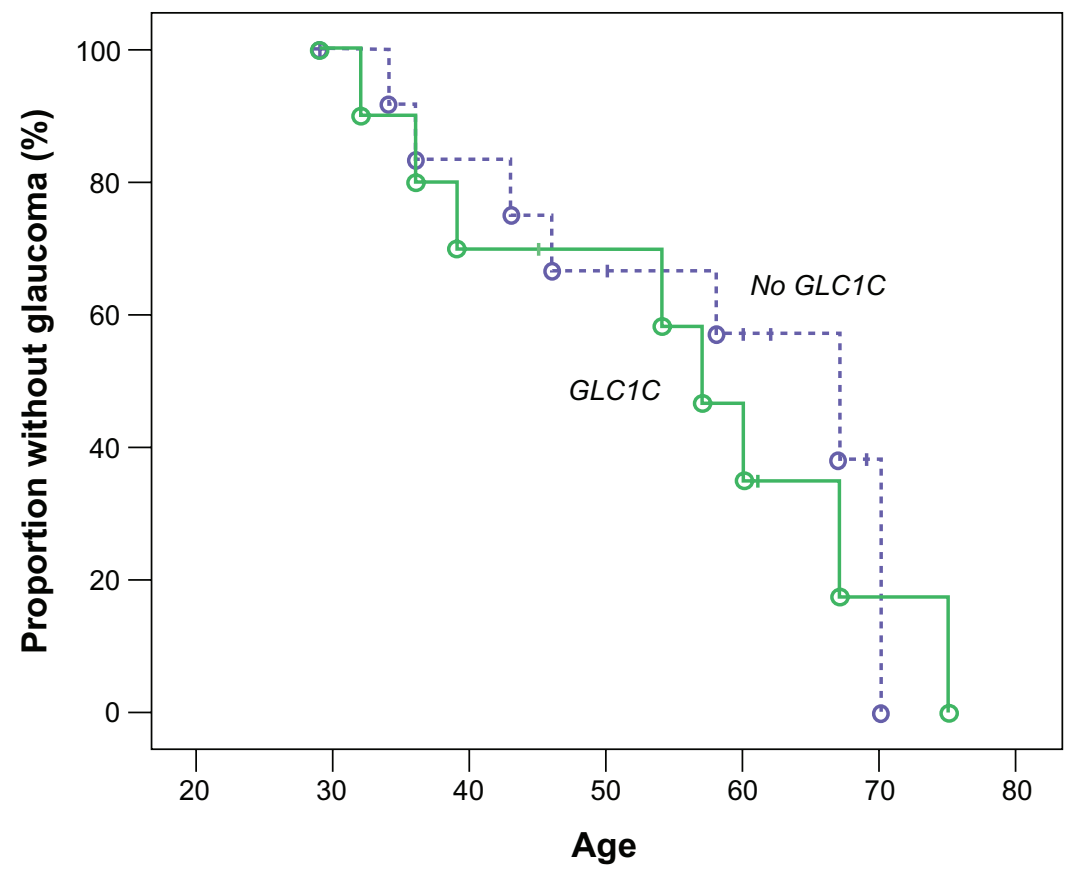

Figure 2 T377M carriers: Probability of developing glaucoma with advancing age for GLCIC and non-GLCIC individuals (Kaplan-Meier plot).

to local men in order to bring "new blood" into the village. In the study by Hewitt et al, ${ }^{16}$ six pedigrees shared the same "Greek" haplotype: the Chrysovitsa family, 2 Australian families, 2 USA families of Greek origin, and 1 family from FYROM, which is in close geographic proximity to Epirus. Furthermore, we had oral information from the examined patients that the two Australian families as well as one from the two US families originated from the Epirus region. In another recent paper from Croatia ${ }^{25}$ a small isolated village called Veli Brgud in the mountains of the Istrian peninsula (population 550), with a previously reported high prevalence of early onset POAG, was investigated. Nine out of 16 POAG patients that were examined, carried the T377M MYOC mutation. There has been no haplotype analysis so far to link the above cases to the known "Greek" haplotype, but the distance from this village to the Epirus Region is about $800 \mathrm{~km}$ in straight line. It is conceivable that all these cases in southeastern Europe may point to a common founder, with family members migrating to different places of the region over the last several centuries.

Table 3 Comparison of clinical features in T377M MYOC carriers with POAG versus other groups of individuals from Epirus, Greece

\begin{tabular}{lllll}
\hline Groups & $\begin{array}{l}\text { Mean }( \pm \text { SD) age at } \\
\text { diagnosis (years) }\end{array}$ & $\begin{array}{l}\text { Mean }( \pm \text { SD) age at } \\
\text { examination }(\text { years) }\end{array}$ & $\begin{array}{l}\text { Mean }( \pm \text { SD) max IOP } \\
(\mathbf{m m H g})^{\mathbf{a}}\end{array}$ & $\begin{array}{l}\text { Mean }( \pm \text { SD) max } \\
\text { cup/disc ratio }\end{array}$ \\
\hline $\begin{array}{l}\text { T377M carriers with POAG } \\
(\mathrm{n}=15)\end{array}$ & $51.0(13.9)$ & $61.5(17.5)$ & $31.9(8.5)$ & $0.67(0.2)$ \\
$\begin{array}{l}\text { Sporadic POAG without } \\
\text { T377M ( } \mathrm{n}=79)\end{array}$ & $63.1(11.0)$ & $70.0(10.0)$ & $28.1(7.1)$ & $0.60(0.21)$ \\
$\begin{array}{l}\text { Chrysovitsa POAG and OHT } \\
\text { without T377M }(\mathrm{n}=12)^{\mathrm{a}}\end{array}$ & $48.0(16.9)$ & $51.7(17.3)$ & $24.9(4.2)$ & $0.49(0.28)$ \\
$\begin{array}{l}\text { Familial POAG without } \\
\text { T377M }(\mathrm{n}=12)\end{array}$ & $66.8(9.8)$ & $76.4(12.9)$ & $29.1(6.3)$ & $0.69(0.18)$ \\
Controls $(\mathrm{n}=124)$ & - & $74.2(8.4)$ & $14.6(2.2)$ & $0.25(0.1)$ \\
\hline
\end{tabular}

${ }^{\mathrm{a}}$ Four individuals were sporadic POAG cases and 8 were from the Chrysovitsa GLCIC family ( 3 with POAG and 5 with OHT).

Abbreviations: $\mathrm{OHT}$, ocular hypertension; POAG, primary open-angle glaucoma. 


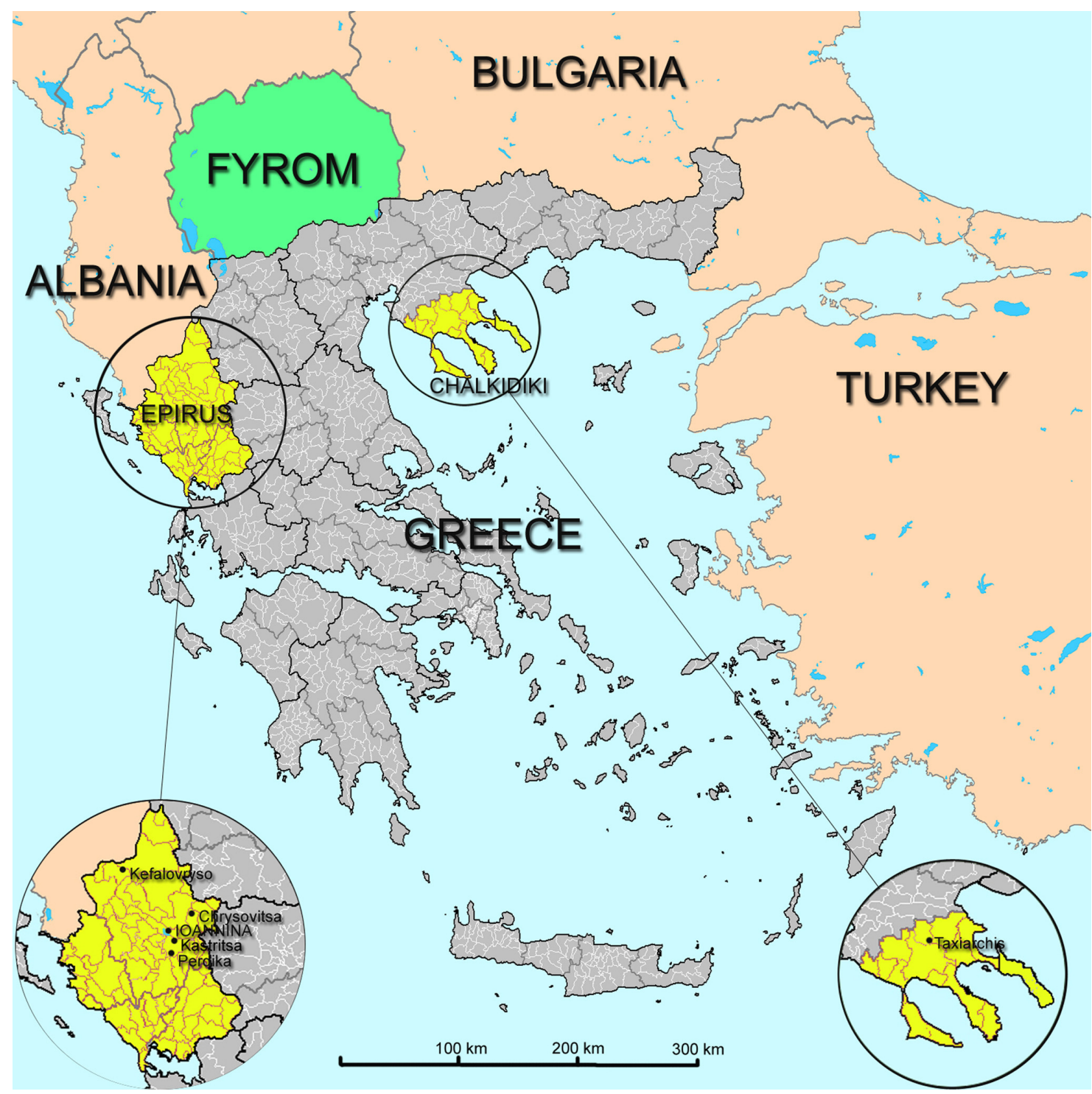

Figure 3 Map of Greece and bordering countries showing the location of the T377M MYOC carriers.

In summary, 2 isolated small Greek villages, known to be enriched for glaucoma, Chrysovitsa from our study and 1 at $300 \mathrm{~km}$ distant from it, were shown to harbor the T377M MYOC mutation on the same haplotype, a Greek founder mutation probably originating from the Epirus region. Furthermore, in our study, the mutation was found in relatively high proportion in familial POAG cases but seems rare among sporadic cases from the same region, while there was no mutation carrier found in the control group.

\section{Acknowledgments}

We wish to thank all the POAG patients and control individuals for their participation in the study. This work was supported by NIH grants EY10555 (MKW), EY11650
(MKW), EY10572 (MKW), and an unrestricted grant from RPB (MKW).

\section{Disclosures}

The authors report no conflicts of interest. The authors alone are responsible for the content and writing of the paper.

\section{References}

1. Dielemans I, Vingerling JR, Wolfs RC, Hofman A, Grobbee DE, de Jong PT. The prevalence of primary open-angle glaucoma in a population-based study in The Netherlands. The Rotterdam Study. Ophthalmology. 1994;101:1851-1855.

2. Topouzis F, Wilson MR, Harris A, et al. Prevalence of open-angle glaucoma in Greece: the Thessaloniki Eye Study. Am J Ophthalmol. 2007;144:511-519.

3. Quigley HA. Glaucoma: macrocosm to microcosm. The Friedenwald lecture. Invest Ophthalmol Vis Scib. 2005;46:2663-2670. 
4. Tielsch JM, Katz J, Sommer A, Quigley HA, Javitt JC. Family history and risk of primary open angle glaucoma. The Baltimore Eye Survey. Arch Ophthalmol. 1994;112:69-73.

5. Sheffield VC, Stone EM, Alward WL, et al. Genetic linkage of familial open angle glaucoma to chromosome 1q21-q31. Nat Genet. 1993; 4:47-50.

6. Morissette J, Côté G, Anctil JL, et al. A common gene for juvenile and adult-onset primary open-angle glaucomas confined on chromosome 1q. Am J Hum Genet. 1995;56:1431-1442.

7. Avramopoulos D, Kitsos G, Economou-Petersen E, et al. Exclusion of one pedigree affected by adult onset primary open angle glaucoma from linkage to the juvenile glaucoma locus on chromosome 1q21-q31. J Med Genet. 1996;33:1043-1044.

8. Richards JE, Lichter PR, Herman S, et al. Probable exclusion of GLC1A as a candidate glaucoma gene in a family with middle-age-onset primary open-angle glaucoma. Ophthalmology. 1996;103:1035-1040.

9. Stone EM, Fingert JH, Alward WL, et al. Identification of a gene that causes primary open angle glaucoma. Science. 1997;275:668-670.

10. Alward WL, Fingert JH, Coote MA, et al. Clinical features associated with mutations in the chromosome 1 open-angle glaucoma gene (GLC1A). N Engl J Med. 1998;338:1022-1027.

11. Hewitt AW, Mackey DA, Craig JE. Myocilin allele-specific glaucoma phenotype database. Hum Mutat. 2008;29:207-211.

12. Angius A, De Gioia E, Loi A, et al. A novel mutation in the GLC1A gene causes juvenile open-angle glaucoma in 4 families from the Italian region of Puglia. Arch Ophthalmol. 1998;116:793-797.

13. Brezin AP, Adam MF, Belmouden A, et al. Founder effect in GLC1Alinked familial open - angle glaucoma in Northern France. Am J Med Genet. 1998;76:438-445.

14. Faucher M, Anctil JL, Rodrigue MA, et al. Founder TIGR/myocilin mutations for glaucoma in the Quebec population. Hum Mol Genet. 2002;11:2077-2090.

15. Baird PN, Richardson AJ, Mackey DA, Craig JE, Faucher M, Raymond V. A common disease haplotype for the Q368STOP mutation of the myocilin gene in Australian and Canadian glaucoma families. Am J Ophthalmol. 2005;140:760-762.

16. Hewitt AW, Samples JR, Allingham RR, et al. Investigation of founder effects for the Thr377Met myocilin mutation in glaucoma families from differing ethnic backgrounds. Mol Vis. 2007;13:487-492.

17. Allingham RR, Wiggs JL, De La Paz MA, et al. Gln368STOP myocilin mutation in families with late-onset primary open-angle glaucoma. Invest Ophthalmol Vis Sci. 1998;39:2288-2295.

18. Wiggs JL, Allingham RR, Vollrath D, et al. Prevalence of mutations in TIGR/Myocilin in patients with adult and juvenile primary open-angle glaucoma. Am J Hum Genet. 1998;63:1549-1552.
19. Shimizu S, Lichter PR, Johnson AT, et al. Age-dependent prevalence of mutations at the GLC1A locus in primary open - angle glaucoma. Am J Ophthalmol. 2000;130:165-177.

20. Kanagavalli J, Krishnadas SR, Pandaranayaka E, Krishnaswamy S, Sundaresan P. Evaluation and understanding of myocilin mutations in Indian primary open angle glaucoma patients. Mol Vis. 2003;9:606-614.

21. Mackey DA, Healey DL, Fingert JH, et al. Glaucoma phenotype in pedigrees with the myocilin Thr377Met mutation. Arch Ophthalmol. 2003;121:1172-1180.

22. Melki R, Idhajji A, Driouiche S, et al. Mutational analysis of the MYOCILIN gene in patients with primary open-angle glaucoma in Morocco. Ophthalmic Genet. 2003;24:153-160.

23. Puska P, Lemmela S, Kristo P, Sankila EM, Jarvela I. Penetrance and phenotype of the Thr377Met Myocilin mutation in a large Finnish family with juvenile- and adult-onset primary open - angle glaucoma. Ophthalmic Genet. 2005;26:17-23.

24. Petersen MB, Kitsos G, Samples JR, et al. A large GLC1C Greek family with a myocilin T377M mutation: inheritance and phenotypic variability. Invest Ophthalmol Vis Sci. 2006;47:620-625.

25. Zgaga L, Hayward C, Vatavuk Z, et al. High prevalence of glaucoma in Veli Brgud, Croatia, is caused by a dominantly inherited T377M mutation in the MYOC gene. Br J Ophthalmol. 2008;92:1567-1568.

26. Kitsos G, Eiberg H, Economou-Petersen E, et al. Genetic linkage of autosomal dominant primary open angle glaucoma to chromosome $3 \mathrm{q}$ in a Greek pedigree. Eur J Hum Genet. 2001;9:452-457.

27. European Glaucoma Society. Terminology and Guidelines for Glaucoma. Savona, Italy: Editrice DOGMA S.r.1. 2008 ch 1.4.3, p87.

28. Hodapp E, Parrish RK, Andersson DR. Clinical decisions in glaucoma. St. Louis. CV Mosby Company. 1993.

29. Miller SA, Dykes DD, Polesky HF. A simple salting out procedure for extracting DNA from human nucleated cells. Nucleic Acids Res. $1988 ; 16: 1215$

30. Kitsos G, Cote G, Psilas K. An example of dominant heredity in the transmission of primary open-angle glaucoma in a northwestern region of Greece. J Fr Ophtalmol. 1988;11:859-864.

31. Wirtz MK, Samples JR, Kramer PL, et al. Mapping a gene for adultonset primary open - angle glaucoma to chromosome 3q. Am J Hum Genet. 1997;60:296-304.

32. Georgiadès G, Papathanasiou A, Moschovakos A, et al. Etude concernant l'interpetation des conditions et des causes de la grande frequence du glaucome au village Taxiarchis de Chalcidique. Scientific Annals of Medical School. 1979;IB:341-351.

33. Wirtz MK, Konstas AG, Samples JR, et al. Myocilin variations and familial glaucoma in Taxiarchis, a small Greek village. Mol Vis. 2008;14:774-781
Clinical Ophthalmology

\section{Publish your work in this journal}

Clinical Ophthalmology is an international, peer-reviewed journal covering all subspecialties within ophthalmology. Key topics include: Optometry; Visual science; Pharmacology and drug therapy in eye diseases; Basic Sciences; Primary and Secondary eye care; Patient Safety and Quality of Care Improvements. This journal is indexed on Submit your manuscript here: http://www.dovepress.com/clinical-ophthalmology-journal

\section{Dovepress}

PubMed Central and CAS, and is the official journal of The Society of Clinical Ophthalmology (SCO). The manuscript management system is completely online and includes a very quick and fair peer-review system, which is all easy to use. Visit http://www.dovepress.com/ testimonials.php to read real quotes from published authors. 